\title{
The Influence of Organizational Commitment, Implementation of Accounting Information System and Workplace Environment to The Performance of Work Unit
}

\author{
Ratna Djuwita \\ Ministry of Works and Public Housing \\ Roebiandini Soemantri \\ Department of Accounting - Faculty of Economics and Business \\ Universitas Padjadjaran \\ Gia Kardina Prima \\ Department of Accounting - Faculty of Economics and Business \\ Universitas Padjadjaran
}

\begin{abstract}
This study aims to obtain empirical evidence on the influence of organizational commitment, implementation of accounting information system and workplace environment affected to the performance of work unit at the Ministry of Public Works and Housing. This study method used survey research with the target population studied is the unit of echelon II work unit that prepares the report of the Government Institution Performance unit (Laporan Kinerja Instansi Pemerintah) in the Ministry of Public Works and Housing. This research design used descriptive approach by using questionnaires to collect data on 122 respondents in 67 work units consists of (1) head of work unit (2) administrator official (3) supervisor officer (4) staff, this research hypothesis test using multiple regression analysis models. The results show that (1) organizational commitment positively affected to the performance of work unit at the Ministry of Public Works and Housing (2) Implementation of Accounting Information System positively affected to the performance of work unit at the Ministry of Public Works and Housing (3) Work environment positively affected at the Ministry of Public Works and Housing.
\end{abstract}

Keywords: Organizational commitment; Accounting information system; Workplace environment; Performance

\section{Introduction}

The results of infrastructure development performance, not only produce physical infrastructure alone but also reduce the gap between regions in the effort of equitable development. Infrastructure development from year to a year experiencing dynamics to the increasing demands of society, as well as the result of political policies that occur.
In the sector of the performance of infrastructure development, not satisfactory seen performance accountability assessment by 2015 by MENPAN-RB to the performance of Ministry of Public Work and Housing (Ministry of PUPR) with value 68,13 or category "B." In previous years, the Ministry of Public Works scored was 64 or "B" categories in 2014 and the value of 73.34 or the "BB" category in 2013. It can be seen that there 
are significant differences in value for three consecutive years, this shows the trend of Ministry Public Work and Housing performance up and down influenced by many factors such as political policy and human resources, and others.

Currently, the challenge of performance enhancement in organizations has increased along with the struggle to manage the quality of the workplace, and accelerated competition among organizations, globalization, the rising expectation of citizens, all have led to organizations' aiming, mostly, on the quality within the contexts of the past few decades (Akdere, 2006 in Al. Zefeiti 2017). Allen et al. (1996) explain that the most critical factors affecting employee performance are an organizational commitment; he also mentioned that the organization's commitment today as a multidimensional work attitude. The importance of organizational commitment to performance can be explained that employees have a high level of organizational commitment will have a positive outlook and more trying to do the best for the benefit of the organization.

In addition to organizational commitment, organizations with information systems will have the ability to effectively detect when business changes need a strategic response. Information systems are instrumental in the field of accounting. The accounting information system is one of the most effective decision-making tools in dealing with complexity and uncertainty (Mulyani, 2015). Accounting information helps managers understand their assignments more clearly and reduce uncertainty before making a decision (Chong 1997). Soudani (2012) showed that although Accounting Information System is beneficial and have an effect on organizational performance to listed companies in Dubai financial market (DFM) there is no relationship between Accounting Information System and performance management.
Some literature also mentions the advantages of using computer-based information systems, among others: can process a number of transactions quickly and integrated, can store and retrieve large amounts of data, can reduce mathematical errors, generate reports in a timely manner in various forms, and can be a decisionmaking tool especially for the type of structured problem (Muntoro, 1994 in Handayani, 2005). Not infrequently found that the accounting information system applied is often not appropriate / not used maximally by users of the system as the application of information systems that provide benefits in performance improvement.

Not only are organizational commitments and accounting information systems critical in improving performance, according to Sekar.C (2011), "The workplace environment impacts employee morale, productivity, and engagement both positively and negatively." It can be said that a fresh, comfortable working environment and meet the standards of worthy needs will contribute to the convenience of employees in performing their duties. Public sector research conducted by Sekar.C (2011) shows that salaries and wages are no longer a factor in the work environment that organizations use to improve productivity.

The significance of the work environment in an organization is explained by Davis (1985) in Permanasari (2013), which states that the work environment in an organization has significance for the individual. It is because the environment will directly or indirectly affect the human inside. Sekar C (2011) attempts to elaborate the previous researchers in examining workplace environment, implementation of the accounting information system, and commitment organization in the ministry of public work and housing affected to unit work performance. 


\section{Theoretical Framework and Hypotheses Development}

Agency theory is a concept that explains the contractual relationship between principal and agent. The principal party is the party who mandates the agent to perform all activities on behalf of the principal in his capacity as a decisionmaker. This agency relationship will create two problems: 1) the occurrence of information asymmetry, and 2) conflicts of interest, occurring due to differences in interests between the agent and the principal so that the agent does not always act in the interests of the owner (Tate and Wendy, 2010).

Contingency theory is used to analyze the design and management accounting system to provide information that companies can use for various purposes and to face competition (Otley, 1980 in Paylosa 2014). Contingency factors chosen in this research are an organizational commitment, implementation of accounting information system and workplace environment. These factors will act as independent variables on the performance of the work unit.

\section{Organizational Commitment and Performance of Work Unit.}

Earlier researchers revealed that organizational commitment is a link between an employee and organizations and also is described as the psychological likings and devotion that employee has to their organization (Faharani 2011, Fulford and Rothman, 2007; Mathieu and Zajac,1990). Moreover, Qureshi et al. (2011) define organizational commitment as "the feeling of responsibility that an employee has towards the mission of the organization."

Suzanto (2012) in their research found results that showed organizational commitment positively related to performance. Cavalluzzo and Ittner (2004) in Umitasari (2016) suggest that management commitment has a positive effect on the development of performance indicators, performance accountability and the use of information performance generated by the implementation of performance measurement systems. High commitment to make individuals care about the fate of the organization and trying to make the organization a better direction so that with a high commitment, the possibility of performance degradation can be avoided. Organizational commitment is an individual's identification of the organization and its purposes and intends to maintain its membership (Koesmono, 2007).

Based on the description above, we propose a hypothesis:

Hypothesis 1: organizational commitment will influence significantly to the performance of work units.

\section{Implementation of accounting information system and performance work unit.}

Information systems in a company is a tool that helps smooth the task and easy way in coordinating between the existing parts because the information system will help to monitor and take decisions to run the company (Baridwan, 2002). The information provided by Accounting Information Systems revolves around, information relating to the results of processing transactions that more financial organizations (Mulyani, 2015).

Accounting Information Systems (AIS) is a tool which, when incorporated into the field of Information and Technology systems (IT), are designed to help in the management and control of topics related to the organization economicfinancial area. But the stunning advance in technology has opened up the possibility of generating andusing accounting information from a strategic viewpoint (El Louadi, 1998 in Soudani 2012). 
The accounting information system has a related field of accounting and management decision-making. According to Nicolau (2000) in Soudani (2012), the fit of the accounting information system to decision making is the information has organizational requirements for information communication and control. Accounting systems provide all levels of management with timely and reasonably accurate information to effect on performance management and help them make decisions which are in agreement with their organization's goals (Anthony G, 2006 in Soudani 2012). The function of the Accounting Information System by Bodnar (2010) on the organization on accounting information system (AIS) consists of five components: (1) the people who operate the system and perform various functions (2) the procedure, both manual and automated, involved in collecting, processing, and storing data about the organization's activities, (3) the data about the organization business process (4) the software used to process the organization's data (5) the information technology infrastructure including computers, peripheral devices, and network communication devices. Accounting systems affect behavior and performance management and have affects across departments, organizations, and even countries (Noellette Conway, 2009 in Soudani 2012). Based on the description above, we propose a hypothesis:

\section{Hypothesis 2: Implementation of the accounting information system will influence significantly the performance of the work unit}

\section{Workplace Environment and the Performance of Work Unit}

The importance of the work environment according to Darvis (2000) in Hariandja (2002) will, directly and indirectly, influence human beings in it is reinforced by evidence showing that tasks can be solved better in a good organizational work environment, there is evidence that managers can influence work environment in the organization or work unit led, the match between individuals and organizations have a very important role in achieving the achievement and individual satisfaction itself in the organization.

The relationship between work, the workplace, and the tools of work, the workplace becomes an integral part of work itself (Sekar C, 2011). The management that dictates how, exactly, to maximize employee productivity center around two major areas of focus: personal motivation and the infrastructure of the work environment. Organizations must have the skills to engage employees in setting common goals, clarify expectations of employee roles, and provide improved performance. Based on the description above, we propose a hypothesis:

Hypothesis 3: Workplace environment will influence significantly the performance of the work unit.

\section{Research Method}

\section{Empirical Design}

The purpose of this research is to find empirical findings of commitment organization, Implementation Of Accounting Information System and workplace environment to the performance of the work unit. This research was conducted to test the hypothesis of the relationship to all variables studied (causal research). The time dimension of the research involves a certain time with many samples (cross-sectional), while data collection methods are done by direct or indirect contact.

\section{Measurement}

Organizational commitment is used to measure how intensive official public sector organizations are committed to 
improving accountability and organizational performance. Commitment to the organization that is the attitude of individual members of the organization to accept and believe the values, organizational goals, willingness to perform high for the progress of the organization and the desire to become members of the organization (Allen, Natalie.J, Meyer, 1996). Implementation Of Accounting Information System (AIS), this variable is seen from AIS component Bodnar stated (2010) that component of AIS proves the most critical role in optimal AIS implementation such as brainware, procedure, database, software and network of AIS. Workplace Environment, this variable is seen from the work environment component that Sekar.C, (2011) suggests that the dimension of the working environment consists of working facilities, working relationships, equality, communication, convenience, and procedures. Performance of Work Unit, In the government sector, performance can be interpreted as an achievement achieved by government employees or government agencies in carrying out services to the community within a period. This instrument is taken from the performance dimension based on Presidential Regulation No. 29 of 2014.

\section{Analysis}

The purpose of this research is to empirically evaluate the organizational commitment, Implementation Of Accounting Information System and workplace environment to performance of work units. To achieve that, we use the F test is done to test whether a simultaneously independent variable affects the dependent variable with a $95 \%$ confidence level $(\alpha=$ $0,05)$ and Partial test (t-test) is done with the intention to test the partial influence between independent variable to a dependent variable with the assumption that another variable is considered constant with $95 \%$ confidence level $(\alpha=0,05)$.

\section{Sample}

The criteria in sampling in this research can be explained as follows work unit which compiled Performance Report of Government Institution (LaKIP) to explain research phenomenon in Ministry of Public Work and Housing . Total number of the sample was involved in this study is 67 units of at ministry of public works and housing

\section{Results}

\section{Descriptive Analysis}

Through the total score of responses from 8 statements submitted on organizational commitment variables, it can be seen that the responses of respondents regarding organizational commitment included in the category of "good." Through the total score of responses from 13 statements submitted regarding variables Implementation of Accounting Information System, it can be seen that the responses of respondents regarding Implementation of Accounting Information System included in the category of "good enough". Through the total score of responses from 12 proposed statements about workplace environment variables, it can be seen that the response respondents regarding Job Circulation included in the category of "good." By using SPSS program application, we get the resulting output of the normality test below as presented in Table 1.

Table 1. Normalitas Test - One sample kolmogrov-Smirnov Test

\begin{tabular}{|l|l|}
\hline Results & Unstandardiz ed Residual \\
\hline Asymp.Sig (2-thailed) & 0.635 \\
\hline
\end{tabular}


Based on SPSS output above obtained Sig value. Normality test using the Kolmogorov-Smirnov method of 0.635 . Since the value of $\mathrm{p}$-value is higher than alpha $(0.635>0,05)$, it can be concluded that the residual data is normally distribute. From each picture above shows that the points spread randomly, do not form a pattern, as well as the points, spread both above and below the zeros on the Y-axis. It can be concluded that there is no heteroskedasticity in the regression model, so the regression model is feasible to be used for subsequent analysis.

Table 2. Multikolineritas Test

\begin{tabular}{ll}
\hline Variables & Value \\
\hline Organizational Commitment $\left(\mathrm{X}_{1)}\right.$ & 1.495 \\
Implementation of AIS $\left(\mathrm{X}_{2}\right)$ & 1.752 \\
Workplace Environment $\left(\mathrm{X}_{3}\right)$ & 2.221 \\
\hline
\end{tabular}

The above results show that the VIF value of each independent variable is below 10, ie Organizational Commitment $\left(\mathrm{X}_{1}\right)=$ 1,495 ; Implementation of Accounting Information System $\left(\mathrm{X}_{2}\right)=1,752$; and
Working Environment $\left(\mathrm{X}_{3}\right)=2,221$. Based on these results it can be concluded that there is no multicollinearity among the independent variables in the model

Tabel 3. Coefficient Regresion

\begin{tabular}{ll}
\hline Model & Value \\
\hline Constant & 1,490 \\
Organizational Commitment $\left(\mathrm{X}_{1)}\right.$ & 0.228 \\
Implementation of AIS $\left(\mathrm{X}_{2}\right)$ & 0.220 \\
Workplace Environment $\left(\mathrm{X}_{3}\right)$ & 0.523 \\
\hline
\end{tabular}

Based on the above output obtained value of the constant and regression coefficients that can be formed multiple line regression equation as follows ; $\mathrm{Y}=$ $1,490+0,228 \mathrm{X}_{1}+0,220 \mathrm{X}_{2}+0,523 \mathrm{X}_{3}+e$. The value $\mathrm{a}=1,490$ means that if the Organizational Commitment $\left(\mathrm{X}_{1}\right)$, Accounting Information System Implementation $\left(\mathrm{X}_{2}\right)$, Working Area $\left(\mathrm{X}_{3}\right)$ is zero (0), then Unit Performance (Y) will be worth 1.490 units. The value $b 1=0.228$ means if the Organizational Commitment $\left(\mathrm{X}_{1}\right)$ increases by one unit, and the other variables are constant, then the Unit Performance (Y) will increase by 0.228 units. The value $\mathrm{b} 2=0.220$ means that if the Accounting Information System Implementation $\left(\mathrm{X}_{2}\right)$ increases by one unit, and the other variable is constant, the Unit Performance (Y) will increase by 0.220 units. The value $b 3=0,523$ means if the Working Environment $\left(\mathrm{X}_{3}\right)$ increases by one unit, and the other variable is constant, the Unit Performance (Y) will increase by 0.523 units.

The result from f-test showed Fcount value of 66.987 with p-value (sig) 0.000 . With $\alpha=0.05$ and degrees of freedom $\mathrm{v} 1=3$, and $\mathrm{v} 2=118(\mathrm{n}-(\mathrm{k}+1))$, then Ftable can be 2,681. Due to the value Fcount $>$ Ftable $(66,987>2,681)$ then $\mathrm{H}_{0}$ is rejected, meaning that the independent variable simultaneously has a significant effect on the Performance of Work Unit (Y). The result from t-tests showed t-count value for Organizational Commitment variable $\left(\mathrm{X}_{1}\right)$ of 2.026 and $\mathrm{t}$-table 1.980 . Because t-table > t-count, then $\mathrm{H}_{0}$ is rejected and $\mathrm{H}_{1}$ accepted, meaning 
Organizational Commitment $\left(\mathrm{X}_{1}\right)$ has a significant effect on the Performance of Work Unit (Y).

The result from t-count value for the variable of Accounting Information System Implementation $\left(\mathrm{X}_{2}\right)$ is 3,710 and t-table 1,980 . Due to the value of $t$-count $>t$-table, then $\mathrm{H}_{0}$ rejected and $\mathrm{H}_{2}$ accepted, it means Accounting Information System Implementation $\left(\mathrm{X}_{2}\right)$ has a significant effect on Unit Performance (Y). Result from tcount for Workplace environment variables $\left(\mathrm{X}_{3}\right)$ of 5.957 and $t$ table 1.980. Due to the value of $\mathrm{t}$-count $>\mathrm{t}$-table, then $\mathrm{H}_{0}$ rejected and $\mathrm{H}_{1}$ accepted, meaning Work Circuit $\left(\mathrm{X}_{3}\right)$ have a significant effect on Unit Performance (Y).

\section{Discussion}

Organizational commitment variable has a significant influence on the performance of the work unit, indicated by the level of significance (Sig) organizational commitment variable of $0.045<\alpha=0.05$. In other words, $\mathrm{H}_{1}$ in this study is supported. The results of the research are in agreement with the research of Al Zefeiti (2017) which states that organizational commitment influences organizational performance, where organizational commitment can be achieved if every individual in the organization has a dimension of Affective Commitment, Continuity Commitment, Normative Commitment to building high performance contextual.

Employees of the Ministry of Public Works and Housing have the desire to work until retirement; it indicates the Ministry of Public Works and Housing where the work is believed to provide good old age guarantees. One of the things that motivate Employees of Ministry of Public Work and Housing to devote their lives to retirement, namely the bureaucracy reform that started in 2008 has had a positive impact in terms of increasing employee income, and better self-development opportunities.

Based on the above discussion shows that agency theory, which explains one of the assumptions about human self-interest and risk revision, is suitable for this research. Also, contingency theory which explains that there is no universal control is appropriate, so management needs to design a more comprehensive system.

Implementation of accounting information system has a significant influence on the performance of the work unit, indicated by the level of significance (Sig) variable implementation of the accounting information system of $0.000<\alpha$ $=0.05$. In other words, $\mathrm{H}_{2}$ in this study is supported. The results of this study are in agreement with Soudani (2012) study which states that the implementation variables of accounting information system have an influence on organizational performance, where the implementation variables of accounting information system can be achieved if the organization executes collection, storage and update of financial data and accounting to be evaluated more so that it can be used as a decision-making material and increase the quality of accounting information, evaluation of targets and internal controls and for the provision of financial transaction facilities.

The availability of information technology and communication infrastructure which is one of its components is hardware becomes the seriousness of Public Works and Housing Minister related to the smoothness of EGovernment by stipulated in Decree of Minister of Public Works and Housing No. 35 / PRT / M / 2016.

Based on the above discussion shows that the agency theory which explains one of the assumptions about the existence of asymmetric information in the organization because of the conflict between members of the organization suitable for this study. In addition, contingency theory that explains that there is no universal control is appropriate, so 
management needs to design a complete accounting information system and answer the problem.

The workplace environment has a significant influence on the performance of the work unit, indicated by the level of significance (Sig) variable implementation of the accounting information system of $0.000<\alpha=0.05$. In other words, $\mathrm{H}_{3}$ in this study is supported, i.e., the work environment has a significant influence on the performance of the work unit. The results of the research are in agreement with Sekar.C (2011) research which states that work environment variables influence organizational performance, where the work environment variable can be achieved on the condition of the leader/supervisor to create comfort quality on all working environment factors to generate employee motivation.

Based on the above discussion shows that the agency theory which explains one of the assumptions about human nature that suggests that humans have a tendency to self-interest (selfinterest) and have limited rationality suitable for this research. In addition, contingency theory that explains that no universal control is appropriate, so management needs to design the right working environment by creating work procedures, working relationships, and creating workplace comfort.

\section{Conclusion and Implication}

\section{Conclusion}

Based on the results of research and discussion on the influence of organizational commitment, the implementation of accounting information systems and workplace environment on the performance of work unit in the Ministry of Public Works and Housing, then at the end of this study, the authors draw conclusions and provide suggestions as follows; 1) Organizational commitment to the Ministry of Public Works and Housing has been going well, 2) Organizational commitment gives a positive and significant effect of $7.39 \%$ on the performance of the work units. This indicates that an increase in organizational commitment will also improve the performance of the work unit, 3) Implementation of accounting information system at the Ministry of Public Works and Housing has been running quite well, 4) Implementation of accounting information system gives positive and significant influence $18.01 \%$ on the performance of the work unit. This shows that the implementation of accounting information system that runs well will improve the performance of the work unit, 5) The working environment at Ministry of Public Works and Housing is considered good, 6) Work environment gives positive and significant effect $37.62 \%$ on work unit performance. It indicates that a good working environment will improve the performance of the work unit, 7) Organizational commitment, implementation of the accounting information system, and work environment provides a significant simultaneous (joint) effect of $63.0 \%$ on the performance of the work unit while the remaining $37.0 \%$ is influenced by other factors not observed in this study.

\section{Implication}

In line with the research background and the results of the research discussions conducted, then some suggestions that can be delivered to achieve satisfactory work unit performance through the implementation of organizational commitment, the implementation of accounting information systems and work environment, Improve the implementation of decisions on organizational commitment through indicators "Employees of Ministry Public Work and Housing willing to complete the work on time". Improvements to these indicators one of them with a clear reward and punishment for employees who complete the work on time so that it can 
motivate employees to be more committed. In addition, organizational commitment can be through a clearer working procedure that takes into account the allocation of work time and the target volume of tasks of all human resources, so that human resources can work seriously under existing working procedures.

Improve the implementation of accounting information system through several indicators that are considered less good, among others: 1) "Regular system supervision" indicator. Against these indicators is to carry out monitoring activities of the system once a week and made responsible for monitoring, 2) The "asset information indicator presented in the SIMAK-BMN application is used in decision making". Against these indicators can be improved by presenting updating data of state property (BMN) continuously so that information is presented more accurately so that the leader can obtain the latest information. 3) The "cost information/ cost/cost indicator displayed in the SAIBA application is used for decision making." Against these indicators can be improved by the presentation of data cost/ cost/load more accurate so that the leadership can obtain the latest information, 4) Helpdesk indicator helps with interruptions/difficulties. These indicators can be improved by providing more competent helpdesk operators and responding to user complaints. 5) Indicator "software can provide Forecasting information ". Against these indicators can be improved by making the potential column of future financial position through accurate calculations.

Improving the work environment through several indicators including; 1) Mentoring by supervisor" indicator. Against these indicators can be improved by arranging a team of mentors who manage several managers and scheduled once a month. Approach methods used are lectures, games, and discussions. In the delivery, each material takes 60 minutes (one hour), 2) Indicators of "equal training opportunities". Against these indicators can be enhanced by capturing the ability of employees and arranging appropriate training, in addition to disseminating information to participants quickly and accurately, 3) The "discussion forum" indicator. The indicators can be improved by holding monthly scheduled discussions and bringing unqualified sources.

\section{References}

Al Zefeiti, Salim Musabah, 2017. The Influence of Transformational Leadership Behaviours on Organizational Commitment in Omani Governmental Organizations. International Journal of Business and Management 12.4: 111.

Allen, Natalie J., and John P. Meyer, 1996 . Affective, continuance, and normative commitment to the organization: An examination of construct validity. Journal of vocational behavior Vol. 49 (3): 252-276.

Baridwan, Zaki 2002. Accounting System. Preparation of Procedures and Methods.

Bodnar, George H; Hopwood. William S. 2010. Accounting Information System, 10th ed. Pearson. .

Chong, V.K. dan Kar Ming Chong, 1997. Strategic Choices, Environmental Uncertainty and SBU Performance: A Note of the Intervening Role of Management Accounting Systems. Accounting and Bussiness Research, Vol 27 (4): 268-276.

Farahani, M., Taghadosi, M., Behboudi, M. 2011. An exploration of the relationship between transformational leadership and organizational commitment: The 
moderating effect of emotional intelligence: Case study in Iran. International Business Research, 4(4), 211-217.

Fulford, M.D., Rothman, R. 2007. Effective HR strategies for enhancing the organisational commitment of HIVpostive employees. Journal of Organizational Culture, Communication and Conflict, 11(1), 91-103.

Handayani, R. 2010. Analysis of Factors Determining the Information Systems Flexibility of Public Sector Organizations. Journal of Accounting and Finance, 12 (1): 2640.

Hariandja, Marihot Tua Efendi, 2002. Human Reources Management Grasindo.

Heny Sidanti, 2015. Influence of Work Environment, Work Discipline and Work Motivation to Performance of Civil Servant In Secretariat of DPRD of Madiun Regency. JIBEKA Journal Vol. 9 (1): 44 - 53

International Journal of Information Science \& Technology, 6(2).

Koesmono, 2007. The influence of leadership and task demands on organizational commitment with moderation variables nurse motivation Hospital Surabaya private." Journal of Management and Entrepreneurship 9.1 (2007): pp-30.

Paylosa, Fanny, 2014. The Influence of Business Strategy And Decentralization To The Relationship Between The Use Of Information Management Accounting System And Managerial Performance. Accounting Journal 2 (1).
Permanasari, Ragil, 2013. Influence of Motivation and Work Environment to Performance PT. Augrah Raharjo Semarang. Management Analysis Journal 2.2.

Presidential Regulation No. 29 of 2014.

Sajady, H., Dastgir, M., \& Hashemnejad. 2008. Evaluation of the effectiveness of accounting information systems.

Sekar Chandra, 2011. Workplace Environment And Its Impact On Organisational Performance In Public Sector Organisations. International Journal of Enterprise Computing and Business Systems Vol.1 (1).

Soudani, S. N. 2012. The usefulness of an accounting information system for effective organizational performance. International Journal of Economics and Finance, 4(5), 136.

Tate, Wendy L., et al, 2010. An agency theory perspective on the purchase of marketing services." Industrial Marketing Management 39.5: 806819. 